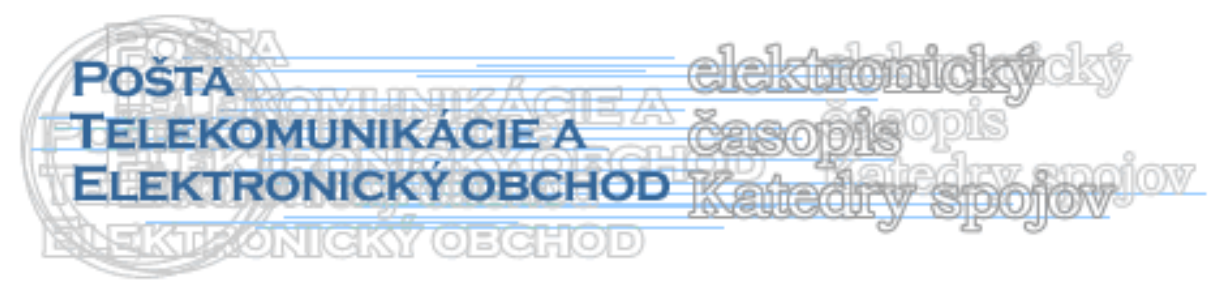

\title{
SELECTED TOUCHLESS TECHNOLOGIES IN SUPPLY CHAIN
}

\author{
Iveta Kremeňová ${ }^{1}$, Dominika Koncová ${ }^{2}$
}

\begin{abstract}
In the Paper, there are identified selected touchless technologies with the examples of their use in specific areas of supply chain and there are also stated benefits and drawbacks of those selected technologies. Paper is further oriented on the RFID technology and possible combination of RFID with NFC or OCR technologies.
\end{abstract}

Keywords: touchless technologies, RFID, NFC

\section{Introduction}

Nowadays, technologies from the environment of Industry 4.0 are booming. For some, those are old technologies as there are discussions of technologies of Industry 5.0, for others those technologies are considerably new. It can be said, that for the Slovak republic, where many companies have not yet started using even many technologies from Industry 4.0, those technologies are suitable to be used.

Traditional jobs, bounded to transferring documents to digital form from its previous paper form, start to decrease as the level of digitization reaches new levels each year. On the other hand, there is increase in the demand for correct and suitable technology and the equipment applied in companies where those traditional jobs were executed. On one hand those technologies, for instance automation and digitization, are great help in processes and systems, on the other hand, those technologies are considerably pricey as well as their implementation brings the decrease in job offers in those companies. This leads to negative effect on employment in the region. However, this is not the problem of this article. [1], [2], [3]

As the technology moves forward and the creation of independent devices starts to be a norm, it is appropriate to state that using wireless devices or devices that does not require use of manual labor of people to open them or to work with them starts to influence people's everyday life. Touchless technology comes forward, enabling new ways of access to those devices. Many people if not all already encountered touchless technologies in their everyday lives, however, not everyone noticed it as those technologies are taken as a common occurrence nowadays. Example of such technologies could represent devices as follows: supermarket's automatic doors, hand dryers in restrooms, automatic soap dispensers etc. Those are in some sense quite old technology, as time has progressed. It depends, what is the device or specific technology meant for to be used as for specifying the way the touchless technology is made for. For example, automatic doors located at some buildings are simply meant for opening and closing those doors after a person or some other device with specific dimensional parameters go through. In other words, the whole system consists of sensors and

\footnotetext{
${ }^{1}$ doc. Ing. Iveta Kremeňová, PhD., University of Žilina, Faculty of Operation and Economics of Transport and Communications, Department of Communications, e-mail: iveta.kremenova@fpedas.uniza.sk

${ }^{2}$ Ing. Dominika Koncová, PhD., University of Žilina, Faculty of Operation and Economics of Transport and Communications, Department of Communications, e-mail: dominika.koncova@stud.uniza.sk
} 
computing devices that enable communication with sensors at the right time. Other devices, such as NFC (Near Field Communication) mobile payment runs on technology NFC, that enables paying for products. In the sense of delivery of products by postal operators, there may be used quite a few types of devices meant either for collecting or delivering postal items. Those devices are, nowadays, usually equipped with advanced technologies, in some cases even touchless. [3], [4], [5], [6], [8], [11], [13]

As a part of devices that belongs under technology Internet of Things (IoT) from Industry 4.0, those IoT things may be divided into two groups of devices. The first group is represented by things, which communicate directly, via touch between communicating devices. Those devices are usually connected by cables into the system. Second group represent touchless devices, for which it is possible to communicate without touch of those devices. A suitable example can be represented by payment via payment terminal, where a person can pay for products either by inserting their card into the device or by nearing their card to the device (this depends on the power of the field through which the communication is performed). Touchless communication may be transferred in different fields. Communication between devices can be transmitted either by magnetic fields, by electric fields or by communicating via ultrasound or radiofrequency. Also, control over devices may be performed either by gestures (those are camera-based, for example Gesturetek, Kinect, NoTouch Touchscreens), by eye tracking, by voice (i.e., Siri, Alexa), by ultrasound control (for instance Elliptic) and by proximity sensors (i.e., thermometer, distance sensors and so on). [7], [8], [9], [10], [15]

This Paper is further oriented on the touchless technology, specifically on humanmachine interface (HMI) technologies. In the section "Results" there are specified touchless technologies applied in logistics sector, their advantages, and disadvantages as well as stated some possible devices, where selected technologies can be applied.

\section{Purpose and methodology}

The aim of the paper is to identify possibilities of implementing touchless technologies in postal company, as well as identifying advantages and disadvantages of such technologies. The explanatory methods used in writing the article fall into the general theoretical methods within the type of method. We excerpted data from secondary data sources, synthesized them based on analogy. Furthermore, there is comparison of benefits and drawbacks of selected touchless technologies as well as number of interested companies in specific touchless technology.

\section{Results}

Possible application of touchless technologies into systems may be found in different areas of use. Depiction of HMI technologies, on which were companies working in 2020 are portrayed in Table 1. As can be seen, the most utilized technologies by companies concern voice recognition, gesture recognition and the use of different sensors. The least worked on technology is proximity touch screen. [10]

Table 1 Over 390 companies were attracted in 2020 by touchless human-machine-interface technologies

\begin{tabular}{|c|l|c|}
\hline No. & Selected HMI touchless technologies & Attracted companies in 2020 \\
\hline 1 & Technology of voice recognition & 110 \\
\hline 2 & Technology of camera-based gesture & 69 \\
\hline 3 & Technology of motion sensor fusion & 53 \\
\hline 4 & Short-range wireless technology & 37 \\
\hline 5 & Technology of photodiode sensor & 16 \\
\hline 6 & Technology of ultrasound or radar-based gesture & 13 \\
\hline
\end{tabular}




\begin{tabular}{|c|l|c|}
\hline 7 & Technology of eye-tracking & 12 \\
\hline 8 & Technology of proximity touch screen & 8 \\
\hline & Total & $>\mathbf{3 1 8}$ \\
\hline
\end{tabular}

Source: [10]

It is expected that the market with touchless technology will grow in timeframe of 2019-2030 by $9 \%$ in the sense of compound annual growth rate (CAGR). The main benefits of non-contact technologies working based on HMI are safety, simplicity of use and conserving of energy sources depending on used technology and the settings of the device. Other pros and cons of selected technologies are stated in the Table 2. [10], [12]

Table 2 Selected pros and cons of specific touchless control technologies.

\begin{tabular}{|l|l|l|}
\hline Technologies & \multicolumn{1}{|c|}{ Advantages } & \multicolumn{1}{|c|}{ Disadvantages } \\
\hline $\begin{array}{l}\text { Camera-based } \\
\text { gesture } \\
\text { control }\end{array}$ & $\begin{array}{l}\text { Ability to sense several people } \\
\text { simultaneously, up to } 8 \text { meters. }\end{array}$ & $\begin{array}{l}\text { Require up to 3 sensors, which } \\
\text { increases costs of technology. }\end{array}$ \\
\hline Voice control & $\begin{array}{l}\text { Independent form the time of day } \\
\text { can discern voice, are miniature, } \\
\text { with low procurement cost. }\end{array}$ & $\begin{array}{l}\text { There is a restriction in the area } \\
\text { with background communication } \\
\text { noise. }\end{array}$ \\
\hline $\begin{array}{l}\text { Eye-tracking } \\
\text { control }\end{array}$ & $\begin{array}{l}\text { Does not need to sense any other } \\
\text { gestures or voices to sense } \\
\text { movement of eyes. }\end{array}$ & $\begin{array}{l}\text { One device may recognize only } \\
\text { movements of eyes of one person } \\
\text { while having a suitable light } \\
\text { condition. }\end{array}$ \\
\hline $\begin{array}{l}\text { Ultrasound } \\
\text { control }\end{array}$ & $\begin{array}{l}\text { Suitable device for discerning } \\
\text { ultrasounds around the device } \\
\text { 24/7. It has a lower consumption of } \\
\text { power, and it is low cost. }\end{array}$ & $\begin{array}{l}\text { The device can sense ultrasound up } \\
\text { to 0,61 cm, but the ultrasound in } \\
\text { itself may influence animals in the } \\
\text { area. }\end{array}$ \\
\hline $\begin{array}{l}\text { Proximity } \\
\text { sensor }\end{array}$ & $\begin{array}{l}\text { The device consumes low amounts } \\
\text { of power but is combined with } \\
\text { touch screen. }\end{array}$ & $\begin{array}{l}\text { The device can sense only within } \\
15 \mathrm{~cm} \text { radius. }\end{array}$ \\
\hline
\end{tabular}

Source: [7], Touch Display Research, Touch and Emerging Display Monthly Report, 2014

In short, there are 5 types of touchless technologies altogether that can react to and recognize gestures, voice, facial features, have touchless sensing or owning personal devices connected to smartphones through which whole technology operates. [14], [16]

From those aforementioned touchless technologies, in logistics and supply chain are commonly applied primarily RFID technologies that are based on radio-frequency communication as a type of sensor. Technology RFID (Radio Frequency Identification) is based on passive and active tag, or both tags that are active. An RFID tag is a label consisting of metal elements creating a coil that is able to record information about the product to which this tag is adhered to. RFID is technology created for identifying, tracking, and tracing shipments and consignments in supply chains. It was expected that RFIDs would supplant barcodes in the future, however, there appeared to be obstacles that prevented full-scale implementation of RFIDs in all fields. A depiction of the RFID system is shown in Figure 1. [17], [18], [20]

Intelligent logistics centers based on RFID technology have the operational prerequisites to increase the efficiency of their own operations, as well as to develop novel service models for their customers. Monitoring material flows and handling processes efficiently leads to an important approach to advancing cost efficiency throughout the supply chain, but it further comprises safety and security aspects. Disadvantages of RFID technology 
may lay also in environmental burden, as they are starting to create a considerable amount of waste yearly. [17], [21]

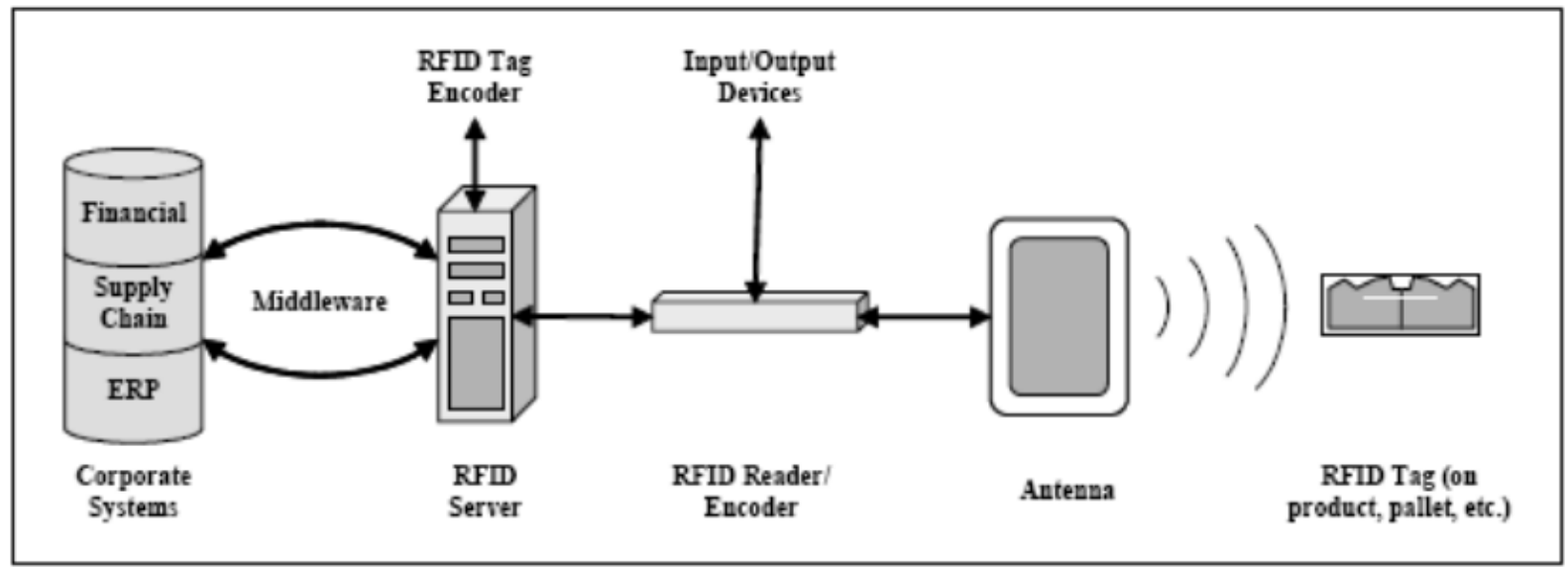

Figure 1 Understanding Radio Frequency Identification (RFID) and Its Impact on the Supply chain. (Source: [18])

To further improve efficiency of processes and to make all supply chain moves faster than now, it is suitable to select services with automatic identification (Auto ID services). Auto ID services may be specified either for selected company or areal specific in the sense of provided services. Some of those work specifically only on RFID technology, for other services, there is need to add technology such as OCR (Optical Character Recognition) for example to enhance abilities provided by those technologies. Services, in which may be applied automatic identification, are stated in the Table 3. [17]

Table 3 Services for application of Auto IDs.

\begin{tabular}{|l|l|}
\hline \multicolumn{1}{|c|}{ Selected Areal Auto ID services } & \multicolumn{1}{c|}{ Selected company specific services } \\
\hline $\begin{array}{l}\text { Vehicle identification, Machine } \\
\text { identification, Container identification, } \\
\text { Person identification }\end{array}$ & $\begin{array}{l}\text { Product identification, Status in the supply } \\
\text { chain, Tagging service }\end{array}$ \\
\hline $\begin{array}{l}\text { Machine supervision and allocation, } \\
\text { Personnel controlling and allocation }\end{array}$ & $\begin{array}{l}\text { Provision of empty and programmed RFID } \\
\text { tags, Data transfer from RFID server to } \\
\text { different systems, Provision and leasing of } \\
\text { RFID infrastructure }\end{array}$ \\
\hline Vehicle location, Vehicle guidance & Helpdesk, Consulting \\
\hline
\end{tabular}

Source: [17]

RFID technology is not the only possible way to identify and to track specific products. On the other side, other technologies, such as NFC tags, usually costs more than RFID tags. For customers, however, it is more preferred to spent less for transport costs, thus technology of NFC is not yet so widespread in the sense of tracking. Though, combination of NFC and RFID may lead to fully automates disposal logistics, where sensors integrated in appropriate locations enable identification and weighing as well as monitoring empty bins that need to be cleaned. NFC is however very suitable for contactless payments which implements use of IoT technologies. [19], [20]

\section{Conclusion}

All of touchless technologies helps to avoid touching devices by many people, which helps to decrease transmittance of contagious diseases via surface of those devices. Another benefit of using such technologies helps people to do tasks effectively while collecting data quickly. The disadvantage may be the constant acquisition of information, which leads to 
increased demand for the used energy sources, the resilience of the materials from which the individual components of the device are made, as well as the potential risk of information leakage in a hacker attack.

\section{References}

[1] Koncova, D., Kremenova, I.: Identification of disruptive exponential technologies of Industry 4.0, Pošta, Telekomunikácie a Elektronický obchod, Vol. I, 2021, s. 10-15, ISSN 1336-8281.

[2] Koncova, D., Kremenova, I.: Sú súčasné chatboty využívané poštovými operátormi poskytujúcimi univerzálnu službu v rámci EÚ postačujúce?, Pošta, Telekomunikácie a Elektronický obchod, Vol. I, 2021, s. 16-21, ISSN 1336-8281.

[3] Ahmed, S., Kalsoom, T., Ramzan, N., Pervez, Z., Azmat, M., Zeb, B., Rehman, M.U.: Towards Supply Chain Visibility Using Internet of Things: A Dyadic Analysis Review, Industry 4.0 and Smart Manufacturing - Sensors, Vol. 21, č. 4158, 2021, s. 1-24, ISSN 1424-8220.

[4] Industry Insights - Invivo: Touchless tech, today and tomorrow, 2020, available online 28.9.2021, retrieved from <https://invivo.com/touchless-tech-today-and-tomorrow/>.

[5] Greetly: What Is Touchless Technology? | No-Touch Visitor Management System, 2020, Retrieved 28.9.2021 from <https://www.greetly.com/blog/what-is-touchlesstechnology>.

[6] Rothman, P.: Contactless Technologies Create a Touch-Free Future | Security Info Watch, Security Business, 2020, s. 44-45, available online 29.9.2021, retrieved from $<$ https://www.securityinfowatch.com/covid-19/article/21151568/contactlesstechnologies-create-a-touchfree-future $>$.

[7] Colegrove, J.: New trends in touch, Information Display, Vol. 30, č. 4, 2014, s. 24-27, ISSN 0362-0972.

[8] Chiarelli, N.: Are we entering a touch-free world?, Unlimited - Trends, 2020, available online 1.10.2021, retireved from <https://www.unlimitedgroup.com/news/are-weentering-a-touch-free-world/>.

[9] Koetsier, J.: This new ultrasound touchless gesturing tech lets you control your Android phone like Xbox Kinect | VentureBeat, 2013, available online 29.9.2021, retrieved from <https://venturebeat.com/2013/10/02/this-new-ultrasound-touchlessgesturing-tech-lets-you-control-your-android-phone-like-xbox-kinnect/>.

[10] Colegrove, J.: Technology Assists: Touchless Thermometer, Distance Sensors, Gesture Control and Proximity Touch Screen | SEMI, 2020, available online 29.9.2021, retrieved from <https://www.semi.org/en/blogs/technology-trends/technology-assiststouchless-thermometer-distance-sensors-gesture-control-and-proximity-touch-screen>.

[11] Buldeo Rai, H., Verlinde, S., Macharis, C.: Unlocking the failed delivery problem? Opportunities and challenges for smart locks from a consumer perspective, Research in Transportation Economics, Vol. 87, 2021, s. 100753 (1-7), ISSN 0739-8859.

[12] Fernando, J.: Compound Annual Growth Rate (CAGR), Investopedia, 2021, available online 29.9.2021, retrieved from $<$ https://www.investopedia.com/terms/c/cagr.asp $>$.

[13] Turska, S., Madlenakova, L.: Concept of Smart Postal Mailbox, Transportation Research Procedia, Vol. 40, 2019, s. 1199-1207, ISSN 2352-1465.

[14] Stein, M.: 5 types of touchless technology to use throughout your workplace | Envoy, 2020, available online 30.9.2021, retrieved from $<$ https://envoy.com/blog/5-types-oftouchless-technology-in-the-workplace/>.

[15] Linder, C.: Ready for a World of No-Touch Touchscreens?, Popular Mechanics, 2020, available online 1.10.2021, retrieved from $<$ https:/www.popularmechanics.com/technology/design/a33434922/no-touch- 
touchscreen/>.

[16] Maney, K.: Technology for a no-touch world, Strategy+business, 2020, available online 30.9.2021, retrieved from $<$ https://www.strategybusiness.com/blog/Technology-for-a-no-touch-world>.

[17] Eckhardt, J., Rantala, J.: The Role of Intelligent Logistics Centres in a Multimodal and Cost-effective Transport System, Procedia - Social and Behavioral Sciences, Vol. 48, 2012, s. 612-621, ISSN 1877-0428.

[18] Maloni, M., DeWolf, F.: Understanding Radio Frequency Identification (RFID) and Its Impact on the Supply Chain, While Paper, 2006, s. 1-44.

[19] Revolutionising logistics with NFC, Sciant, 2019, available online 30.9.2021, retrieved from $<$ https://medium.com/sciant/revolutionising-logistics-with-nfc-d6ccaf0e12c $>$.

[20] Vaculik, J., Michalek, I., Kolarovszki, P.: Principles of selection, implementation and utilization of RFID in supply chain management, Promet - Traffic \& Transportation, Vol. 21, č. 1, 2009, s. 41-48, ISSN 0353-5320.

[21] Bukova, B., Tengler, J., Brumercikova, E.: A Model of the Environmental Burden of RFID Technology in the Slovak Republic, Sustainability, Vol. 13, č. 3684, 2021, s. 110, ISSN 2071-1050.

\section{Grant support}

The Paper is published with the support of project VEGA 1/0518/19. This research has been further supported by the University of Zilina in the scope of Institutional research 1/KS/2020, by Project K-21-015-00 and Project CIS by Ministry of Educations SR. 